\title{
PENGARUH BIAYA DISTRIBUSI TERHADAP JUMLAH PENJUALAN PUPUK PADA PT. PERTANI (PERSERO) CABANG BENGKULU
}

\section{QUANTITY TRANSACTION INTO EFFECT EXPENDITURE DISTRIBUTIONS ON PT. PERTANI (PERSERO) BENGKULU}

Rika Dwi Yulihartika

Program Studi Agribisnis, Fakultas Pertanian, UNIVED

\begin{abstract}
ABSTRAK
Distribusi merupakan bagian dari pemasaran yang bertujuan mendapatkan barang yang tepat dan tempat yang tepat dengan biaya yang efisien. Oleh karena itu peranan distribusi sangat penting dalam suatu perusahaan. PT. Pertani (Persero) Cabang Bengkulu adalah perusahaan yang bergerak dibidang pendistribusian pupuk. Sebelum dijual pupuk dikirim dari pabrik ke gudang distributor terlebih dahulu, setelah itu dialokasikan untuk beberapa wilayah yang akan di distribusikan sesuai dengan permintaan pasar.Metode pengumpulan data dalam penelitian ini adalah dengan studi pustaka dan studi lapangan, dalam studi lapangan terdiri dari wawancara dan observasi. Metode analisis yang digunakan adalah analisis kualitatif dan kuantitatif. Analisis kuantitatif digunakan dengan pendekatan statistik menggunakan rumus regresi linear sederhana dan analisis koefisien kolerasi dengan metode Person Product Moment (r). Serta untuk membuktikan apakah ada pengaruh dan hubungan antara biaya distribusi fisik terhadap volume penjualan maka akan digunakan uji hipotesis $\mathrm{t}$ (t-hitung) dan kemudian dibandingkan dengan t-tabel.Hasil analisis yang diperoleh persamaan regresi linear sederhana $\mathrm{Y}=68.615+0,446 \mathrm{X}$ yang berarti bahwa konstanta sebesar 68.615 menyatakan bahwa jika tidak ada pengaruh dari biaya distribusi fisik maka volume penjualan akan tetap sebesar 68.615 atau bahkan tidak ada penjualan sama sekali dan koefisien regresi sebesar 0,446 menyatakan bahwa setiap penambahan 1 unit biaya distribusi fisik akan meningkatkan nilai volume penjualan sebesar 0,446 . statistik $t_{\text {-hitung }}>\mathrm{t}_{\text {-tabel }}(11.366>1,67)$ artinya significan bahwa biaya distribusi fisik berpengaruh terhadap volume penjualan.
\end{abstract}

Kata kunci : biaya, distribusi fisik, volume penjualan

\section{ABSTRACT}

Distribution represent the part activity of marketing which point to get correct goods and correct plance with efficient expense. Therefore distribution role of vital importance in aim peripatetic company is distribution area. PT. Pertani (Persero) on Bengkulu is peripatetic company of distribution fertilizer. Before sold to market, product sent from factory to distributor warehouse beforehand, afterwards in allocation to some region exist in province Bengkulu according to requirement of each region to distributed as according to request of market. Method research is referensi study and discipline study, in field study consist of observation and interview. Used by analysis method is analisys qualitative and quantitative. Quantitative analisys used whit statistical approach used simple linear regression formula and correlation coefficient analysis with person product moment method $(r)$ and also to prove 
do there is relation and influence between distribution channel to purchase volume in thypothesis test ( $t$-hitung $\left.>t_{\text {-tabel }}\right)$. Result of analysis $Y=68.615+0,446 \mathrm{X}$ meaning that constanta equal to 68.615 expressing that if influence from expense of physical distribution purchase volume equal 68.615. and regresi coefficient equal to 0,446 expressing that each addition 1 unit of physical distribution boosted up from purchase volume. Correlation coefficient $(r)=0,612$, value positif correlation with purchase volume and physical distribution boosted. Value coefficient determination equal 0,374 is 37,4\% variable indenpenden of purchase and variable dependen of physical distribution boosted, value $62,6 \%$ other of variabel on variable physical distribution boosted.

Keywords : cost, physical distribution, distribution boosted

\section{PENDAHULUAN}

Pada era globalisasi dan kemajuan dan teknologi informasi dan ekonomi dewasa ini tingkat persaingan antar perusahaan semakin ketat, sehingga masing-masing perusahaan mempunyai kiat tersendiri untuk mempertahankan dan meningkatkan usahanya. Bagi perusahaan yang tidak jeli dan tanggap terhadap perubahan pola hidup konsumen, maka ada kecendrungan perusahaan tersebut akan mundur bahkan pailit.

Tujuan perusahaan dalam suatu perekonomian yang bersaing adalah memperoleh laba yang sebesar-bsarnya sesuai dengan pertumbuhan perusahaan dalam jangka panjang,yang mana telah dicanangkan oleh Direksi PT. Pertani (Persero) tantang Visi Perusahaan adalah “ manjadi Perusahaan Agribisnis yang kompetitif sehat dan berkembang " dengan Misi Perusahaan " mengahasilkan dan memasarkan produk Agribisnis yang memiliki daya saing dalam kualitas, Pelayanan dan harga dalam rangka menunjang Pembangunan Pertanian “

Salah satu faktor yang sangat berperan dalam menentukan tingkat harga penjualan sesuai dengan laba yang diinginkan oleh perusahaan dan mampu berkompotisi dengan harga penjualan dari perusahaan lain adalah biaya distribusi fisik.

Bagi perusahaan yang bergerak dibidang produksi, biaya distribusi fisik pada umumnya meliputi biaya proses produksi , biaya pergudangan, biaya pengendalian persediaan dan biaya transportasi. Kamampuan perusahaan dalam meningkatkan efisiensi biaya produksi fisik selain dapat meningkatkan pelayanan kepada konsumen, juga dapat meningkatkan volume penjualan dan keuntungan perusahaan.

Letak lokasi gudang dan tempat penyimpanan akan mempengaruhi biaya penyimpanan, biaya pengendalian 
persediaan, dan biaya transfortasi. Oleh karena itu Pemimpin perusahaan harus mampu mencari lokasi gudang yang strategis baik dilihat dari tingkat ketersediaan bahan baku, maupun dari sisi pemasaran hasil produksi.

Transfortasi merupakan salah satu kegiatan yang penting bagi perusahaan, karena pemindahan barang dari suatu tempat ke tempat lain dengan waktu tertentu dan pada saat tertentu, selain dapat meningkan pelayanan kepada konsumen juga dapat meningkatkan volume penjualan, dengan demikian konsumen merasa puas terhadap tepatnya waktu pengiriman barang. Kepuasan konsumen ini merupakan media promosi yang sangat menguntungkan perusahaan dalam meningkatkan pelanggan..

Peningkatan volume penjualan sangat penting bagi suatu perusahaan untuk menjamin kelangsungan hidup perusahaan karena dengan volume penjualan yang tinggi merupakan sumber penghasilan utama perusahaan. Dalam meningkatkan volume penjualan bukanlah hal yang mudah karena masing-masing perusahaan berusaha semaksimal mungkin untuk meningkatkan penjualan antara lain dengan mengadakan potongan harga (discount) dan pemberian hadiah-hadiah yang menarik kepada konsumen.

Pada saat ini bidang pemasaran pupuk dan bidang lainnya cukup baik didalam memberikan sumbangan pendapatan perusahaan, bahkan secara Nasional sumbangan Margin bidang pemasaran pupuk terhadap laba usaha mendekati $50 \%$ dari Margin yang diraih Tahun 2009 sedangkan untuk bidang tersebut dimasa yang akan datang masih terbuka peluang untuk ditingkatkan volume penjualannya, mengingat jumlah produksi dan penyaluran pupuk Subsidi masih dibawah kebutuhan Nasional sedangkan pupuk sampai saat ini pemerintah masin mengimport dari luar.

\section{METODE PENELITIAN}

Penelitian ini bersifat deskriftif kuantitatif yaitu meneliti dan berusaha mendapatkan data yang aktual dan akurat. Data tersebut diolah dan dianalisis dengan formulasi matematis kemudian disimpulkan yang merupakan pembahasan dari masalah yang diteliti.

Dalam pembahasan penulis menggunakan metode ananlisis sebagai berikut : Analisis kualitatif yaitu suatu metode analisis yang membandingkan kondisi yang ada pada perusahaan dengan teori-teori dari literatur sehingga dapat ditarik kesimpulan sampai 
sejauh mana peranan distribusi fisik dapat meningkatkan volume penjualan pada PT. Pertani (Persero) Cabang Pemasaran Penyalur Pupuk Bengkulu. Analisis kuantitatif suatu metode analisis dengan menggunakan statistik. $\mathrm{Y}=\mathrm{a}+\mathrm{b} \mathrm{X}$ Dimana nilai $a$ dan $b$ diperoleh dengan menggunakan rumus sebagai berikut :

$$
b=\frac{2 X^{\top} Y^{\top}-\pi \cdot \bar{X} \cdot \bar{Y}}{X^{2}-n \cdot \bar{X}^{2}}
$$

Koefisien korelasi yang digunakan adalah korelasi Pearson yang disimbolkan dengan r dan dirumuskan :

ketangan konsumen pada waktu yang tepat. Sehingga dibutuhkan saluran distribusi untuk menyalurkan produkbtersebut baik melalui perantara maupun tanpa perantara.

Distribusi fisik pada PT. Pertani (Persero) Cabang Bengkulu terdiri dari beberapa tugas yang tersusun dalam sistem yang mencakup tugas yang harus dilaksanakan dalam manajemen distribusi fisik yaitu :

a. Pengangkutan atau transportasi

Transportasi merupakan bagian penting dalam sistem distribusi fisik untuk mengangkut pupuk dari PT. Pertani (Persero) ke distributor. Transportasi juga memberikan manfaat pada sistem logistik dengan menghubungkan fasilitas-fasilitas $\mathrm{r}=\frac{\mathrm{n} \cdot \sum \mathrm{XY}-\sum \mathrm{X} \cdot \sum \mathrm{Y}}{\sqrt{\left\{\mathrm{n} \cdot \sum \mathrm{X}^{2}-\left(\sum \mathrm{X}\right)^{2}\right\}\left\{\mathrm{n} \cdot \sum \mathrm{Y}^{2}-\left(\sum \mathrm{Y}\right)^{2}\right\}} \text { dengan pasar. Keputusan perusahaan dalam }}$ berpengaruh terhadap harga dari pupuk itu sendiri. Juga terhadap ketepatan waktu

\section{HASIL DAN PEMBAHASAN}

Kegiatan Distribusi Fisik Pada PT.

\section{Pertani (persero) cabang Bengkulu}

Keberhasilan suatu perusahaan dalam usahanya bukan saja ditinjau dari besar kecilnya keuntungan yang terlihat dari kemampuan konsumen untuk membeli, ketertarikan konsumen terhadap produk yang dihasilkan. Oleh karena itu dibutuhkan suatu strategi yang tepat misalnya pendistribusian produk sampai pengiriman dan kondisi barang-barang tersebut saat sampai ketempat tujuan.

b. Penyimpanan

Persediaan yang terlalu berlebihan akan merugikan perusahaan karena lebih banyak modal tertanam, pemakaian ruang yang kurang efisien dan banyaknya biaya yang timbul akibat persediaan yang berlebihan tersebut, ssebaliknya persediaan yang terlalu kecil akan merugikan perusahaan karena akan mengganggu kelancaran 
kegiatan perusahaan terutama dalam untuk sampai ketangan distributor dan memenuhi pesanan konsumen. Sehingga konsumen lainnya.

PT. Pertani (Persero) Cabang Bengkulu Berdasarkan data yang diperoleh dari hasil hanya mengirimkan barang sesuai dengan pesanan dari distributor. penjualan pada PT. Pertani (Persero) Cabang Bengkulu dapat dilihat pada Tabel 1. Berdasarkan Tabel 1 volume penjualan Volume Penjualan diatas maka dapat kita lihat persentase Volume penjualan tidak dapat timbul, volume penjualan pada tiap tahunnya. Dari menurun atau meningkat dengan sendirinya tanpa ada pengaruh atau hubungannya dengan faktor-faktor lainnya, dalam hal ini salah satu penyebab timbulnya volume penjualan adalah karena adanya kegiatan saluran distribusi. Tanpa saluran distribusi, akan sulit bagi tahun 2010 volume penjualan mengalami naik turun seiring dengan mengingkatnya jumlah kebutuhan masyarakat terhadap pupuk. Tingkat permintaan pupuk yang terbesar terjadi pada tahun 2013 dengan volume penjualan sebesar 959.479,16 kwantum.

perusahaan dalam memasarkan produknya

Tabel 1. Volume penjualan PT. Pertani (Persero) Cabang Bengkulu tahun 2010 s/d 2014

\begin{tabular}{cccc}
\hline NO & TAHUN & $\begin{array}{c}\text { VOLUME PENJUALAN } \\
\text { (KWANTUM) }\end{array}$ & $\mathbf{( \% )}$ \\
\hline 1 & 2010 & $719.608,33$ & 19,20 \\
2 & 2011 & $763.921,50$ & 20,38 \\
3 & 2012 & $578.191,67$ & 15,42 \\
4 & 2013 & $959.479,16$ & 25,61 \\
5 & 2014 & $727.064,92$ & 19,39 \\
\hline & JUMLAH & $3.748 .265,58$ & 100 \\
\hline
\end{tabular}

Sumber Data : PT. Pertani (Persero) dan diolah ; 2014 


\section{Jumlah Biaya Distribusi Fisik}

Sedangkan untuk biaya saluran distribusi fisik yang dikeluarkan oleh PT. Pertani (Persero) Cabang Bengkulu dari tahun 2010 sampai tahun 2014 ditampilkan pada Tabel 2.

Dari tabel 2 dapat dilihat setiap kenaikan jumlah biaya distribusi fisik yang dikeluarkan oleh perusahaan, hal ini disesuaikan dengan jumlah volume penjualan. Dimana semakin meningkatnya volume penjualan akan semakin banyak juga biaya distribusi fisik yang dikeluarkan oleh perusahaan untuk menyalurkan pupuk sampai ke tangan konsumen, kelancaran perusahaan dalam menyalurkan pupuk adalah salah satu cara untuk mempertahankan konsumennya, dimana konsumen akan merasa puas dengan pelayanan cepat dan tepat yang dilakukan oleh PT. Pertani (Persero) Cabang Bengkulu.

\section{Analisis Regresi}

Analisa data dilakukan bertujuan untuk mengetahui peranan biaya distribusi fisik terhadap volume penjualan pupuk dari tahun 2010-2014. Analisis Regresi sederhana dilakukan dengan bantuan alat analisis program SPSS versi 12,0 for wondows disajikan pada Tabel 3.

Interprestasi dari persamaan linier pada Tabel 3 sebagai berikut :

a. Jika segala sesuatu pada variabelvariabel independen dianggap konstan maka volume penjualan (Y) adalah sebesar Rp 68.615,-

b. Jika terjadi penambahan biaya distribusi fisik sebesar Rp 1000,- maka volume penjualan akan meningkat sebesar Rp 4460 ,-

Tabel 2. Biaya Distribusi Fisik dari Tahun 2010 s/d 2014

\begin{tabular}{|c|c|c|c|}
\hline NO & TAHUN & $\begin{array}{l}\text { JUMLAH BIAYA DISTRIBUSI FISIK } \\
(\mathrm{Rp})\end{array}$ & $(\%)$ \\
\hline 1 & 2010 & $15.272 .166,67$ & 4,88 \\
\hline 2 & 2011 & $61.144 .537,50$ & 19,55 \\
\hline 3 & 2012 & $8.194 .959,43$ & 2,62 \\
\hline 4 & 2013 & $128.790 .466,67$ & 41,17 \\
\hline \multirow[t]{2}{*}{5} & 2014 & $99.389 .700,00$ & 31,78 \\
\hline & JUMLAH & $312.791 .830,3$ & 100 \\
\hline
\end{tabular}


Tabel 3. Analisi Regresi Linier Sederhana

\begin{tabular}{llll}
\hline Variabel & Koefisien & t-hitung & $\alpha$ \\
\hline Konstanta & 68.615 & 11.700 & 000 \\
Biaya distribusi Fisik & $.446^{* *}$ & 11.366 & 0,024 \\
T-tabel=1,67 & $\mathrm{R}=0,612$ & $\mathrm{~F}=129,181$ & $\mathrm{DW}=$ \\
& $\mathrm{R}^{2}=0,374$ & & 2,233 \\
\hline
\end{tabular}

$$
\begin{aligned}
& \text { Sumber : data yang diolah } ; 2014 \\
& * * \text { Signifikan }(\alpha)=5 \% \\
& Y=68.615+0,446 \mathrm{X} \\
& \text { Dimana : } \\
& \mathrm{Y}=\text { Volume Penjualan } \\
& \mathrm{X}=\text { Biaya Distribusi Fisik }
\end{aligned}
$$

Nilai estimasi koefisien regresi variabel biaya distribusi fisik adalah sebesar 0,446 yang artinya setiap penambahan satu satuan volume penjualan akan meningkatkan biaya distribusi fisik sebesar 0,446 satuan. Nilai konstanta sebesar 68.615 pada model regresi menunjukkan bahwa segala sesuatu pada variabel independent dianggap konstan maka volume penjualan (Y) adalah sebesar 68.615 .

\section{Koefisien Korelasi}

Dari hasil korelasi (r) pada Tabel 4 dapat diketahui bahwa besarnya korelasi antara volume penjualan dengan biaya distribusi fisik adalah 0,612. Menunjukkan tanda positif berarti berkorelasi positif. Interprestasi dari besarnya nilai korelasi antara variabel dapat diklasifikasikan sebagai berikut : (Yamin, 2009 : 69) 0,00-0,09 : hubungan korelasi diabaikan $0,10-0,29$ : hubungan korelasi rendah $0,30-0,49$ : hubungan korelasi moderat $0,50-0,70$ : hubungan korelasi sedang $>0,70$ : hubungan korelasi sangat kuat

Tabel 4. Correlations

\begin{tabular}{llll}
\hline & & $\begin{array}{l}\text { Volume } \\
\text { Penjualan }\end{array}$ & $\begin{array}{l}\text { Biaya } \\
\text { distribusi }\end{array}$ \\
\hline Pearson Correlation & Volume Penjualan & 1.000 & .612 \\
& Biaya distribusi & .612 & 1.000 \\
Sig. (1-tailed) & Volume Penjualan &. & .099 \\
$\mathrm{~N}$ & Biaya distribusi & .099 &. \\
& Volume Penjualan & 60 & 60 \\
& Biaya distribusi & 60 & 60 \\
\hline
\end{tabular}


Tabel 5. Hasil Uji T

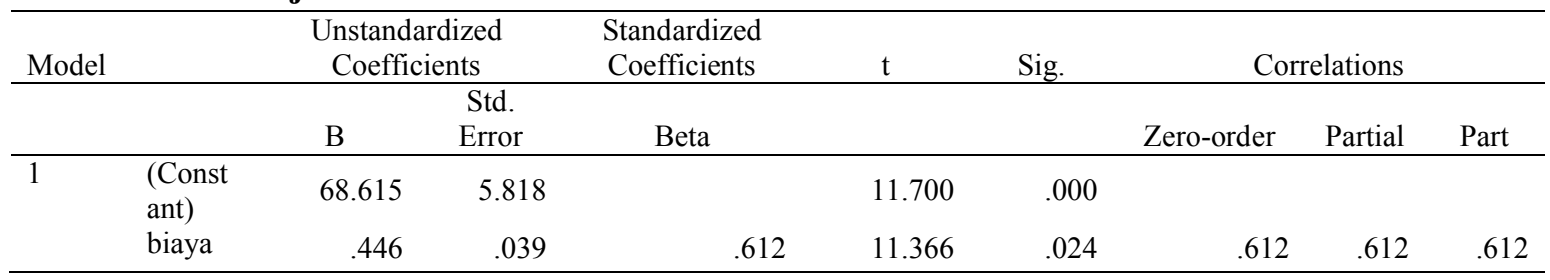

Nilai koefisien determinasinya sebesar 0,374 artinya $37,4 \%$ variabel independen volume penjualan dijelaskan oleh variabel dependen biaya distribusi fisik dan sisanya $62,6 \%$ dijelaskan variabel lain diluar variabel biaya distribusi fisik.

\section{Pengujian Hipotesis}

Pada tabel 3 dapat dilihat bahwa hasil uji simultan diperoleh bahwa F-hitung sebesar 129,181 dengan probabilitas sebesar 0,000 $(\mathrm{p}<\alpha(5 \%))$ sehingga hipotesis no (Ho) ditolak dan menerima hipotesis alternatif (Ha) yang berarti variabel biaya distribusi fisik berpengaruh signifikan terhadap variabel volume penjualan, dengan kata lain jika volume penjualan meningkat maka biaya distribusi fisik juga meningkat. Biaya distribusi fisik disini meliputi biaya pengangkutan dan biaya penyimpanan. Sedangkan hasil uji $\mathrm{T}$ diperoleh T-hitung sebesar 11.366 lebih besar dari T-tabel 1,67 artinya signifikan bahwa biaya distribusi fisik berpengaruh terhadap volume panjualan. Hasil uji $\mathrm{T}$ dapat dilihat pada Tabel 5.

\section{SIMPULAN}

Hasil analisis peranan biaya distribusi fisik dengan volume penjualan pupuk pada PT. Pertani (Persero) cabang bengkulu adalah Y $=68.615+0,446 \mathrm{X}$ yang artinya Segala sesuatu pada variabel-variabel independen dianggap konstan yaitu variabel biaya distribusi fisik, maka volume penjualan (Y) adalah sebesar Rp 68.615,-dan jika terjadi penambahan biaya distribusi fisik sebesar Rp 1000,- maka volume penjualan akan meningkat sebesar Rp 4460,-.

Dari hasil korelasi (r) diketahui bahwa besarnya korelasi antara volume penjualan dengan biaya distribusi fisik adalah 0,612. Menunjukkan tanda positif berarti berkorelasi positif. Hasil uji T diperoleh Thitung sebesar 11.366 lebih besar dari Ttabel 1,67 artinya signifikan bahwa biaya distribusi fisik berpengaruh terhadap volume penjualan. 


\section{DAFTAR PUSTAKA}

Ahyari, Agus, 1999. Efisiensi Persediaan Bahan, Edisi Kedua, Cetakan Kelima, Penerbit Bagian Penerbitan Fakultas Ekonomi Universitas Gadjah Mada, Yogyakarta, hal 35, 56 dan 48.

Buffa S,Elwood dan Rakesh K. Sarin, 1996, Manajemen Operasi / Produksi Modern, Terjemahan N. Agus Maulana MSM, Jakarta : Binarupa Aksara

Garrison, Ray., Noreen, Eric., 2000. Akuntansi Manajerial, Edisi Pertama, Jilid Dua, Buku Satu, Penerjemah Totok Budisantoso, Penerbit Salemba Empat, Jakarta, hal 3.

Handoko, T Hani, 2000, Dasar Dasar Manajemen Produksi dan Operasi Edisi II, Yogyakarta : BPFE

Herjanto, Eddy, 1999, Manajemen Produksi dan Operasi , Jakarta: Grasindo.

Kotler, Philip, 2003. Prinsip-prinsip

Pemasaran, Jilid I. Penerbit Erlangga. Indonesia

Niswonger, C. Rollin E,Fees, Carl S Warren, 2000. Prinsip-Prinsip Akuntansi, Edisi Kesembilanbelas, Cetakan Pertama, Jilid Satu, Penerjemah Alfonsus Sirait dan
Helda Gunawan, Penerbit Erlangga, Jakarta, hal 359.

Rangkuty, Freddy, 2004. Manajemen Persediaan, Edisi Dua, Cetakan Keenam, Penerbit PT. Raja Grafindo Persada, Jakarta, hal 9.

Riyanto, Bambang, 2001. Dasar - Dasar Pembelanjaan Perusahaan, Edisi Keempat, Cetakan Ketujuh, Penerbit Bagian Penerbitan Fakultas Ekonomi Universitas Gadjah Mada, Yogyakarta, hal 78.

Stantion, William, J, 2004. Prinsip Pemasaran. Penerbit Erlangga

Supriyono, A. R, 2000. Perencanaan dan Pengendalian Biaya serta Pembuatan Keputusan, Edisi Kedua, Cetakan Keempat, Bagian Penerbitan Fakultas Ekonomi Universitas Gadjah Mada, Yogyakarta, hal 257.

Sutojo, D. H, Basu, 2004. Azas-azas Marketing, Liberty. Yogyakarta.

Usry, Milton F., Lawrence, H. Hammer., 2004. Akuntansi Biaya Perencanaan Dan Pengendalian, Edisi Kesepuluh, Cetakan Kelima, Jilid Satu, Penerjemah Alfonsus Sirait dan Herman Wibowo, Penerbit Erlangga, Jakarta, hal 25. 